\title{
The (Non-)Seriousness of Culture: The case of the Lithuanian Operetta
}

\author{
Vita Gruodytè \\ Litovska akademija za glasbo in gledališče \\ Lithuanian Academy of Music and Theatre
}

\section{Introduction}

The theme of the operetta, I must admit, has greatly embarrassed me. It must be said that it is a genre a little apart, an intermediate genre, with many ramifications, one that fills a wide space between the opera and the cabaret. "Like all genres, the operetta did not immediately find its true path," said Jacques Offenbach's grandson,

It was based on the Italian opera bouffe and the vaudeville with couplets. We know that in its beginnings it had only one act and two or three characters. ${ }^{\text {' }}$

For a genre as vague as the operetta, with so many different forms and names and so many possibilities of covers, collages, and varied refactoring, ${ }^{2}$ it takes time for it to find its place in a culture. Meanwhile, in the emerging cultures of the early $2 \mathrm{O}^{\text {th }}$ century it was necessary to go fast. To assert one-

1 Jacques Brindejont-Offenbach, Cinquante ans d'opérette [Fifty years of operetta], https://www.artlyriquefr.fr/dicos/Cinquante\%20ans\%20-\%20operette.html.

2 For Jacques Brindejont-Offenbach, one brings together, perhaps too generally under the title 'operetta', three musical genres which are however distinguished from each other by very different qualities: 1 . Opéra bouffe, or operetta-bouffe, which is a parody of the grand opera, which flourished from 1855 to 1870 . 2. Operetta, light and fanciful, the daughter of the comic opera, which caused a furore after the First World War, and whose vogue continued, decreasing, until 1914. Finally, 3. what we will call the musical comedy or musical vaudeville: genres inspired by English and Viennese operettas, with verses on dance tunes (In: Cinquante ans d'opérette). 
self not only politically, but also culturally, it was necessary to rely on 'solid' music genres, tested by time. The national revival of small countries was therefore a serious thing, and culture played a very important role. It was involved not only in the construction of the national identity, but also in its prestige. For this reason, the State Opera (in Lithuanian, Valstybes opera), ${ }^{3}$ throughout the period between the two world wars was the main showcase of the country, a cultural institution par excellence that the Lithuanian government subsidised to the maximum, often to the detriment of other cultural domains.

Already in the past the opera was intimately linked to national revival, especially in the $19^{\text {th }}$ century, with the works of Giuseppe Verdi in Italy or Bedrich Smetana in the Czech Republic. At the beginning of the $20^{\text {th }}$ century, Lithuanian society experienced a similar enthusiasm: "In the early years of independence, our society was interested mainly in opera," said the composer Vladas Jakubenas. " "For the Lithuanian public, the creation of an opera symbolised the consolidation of national consciousness, raised pride and hopes for the future,"s summed up the musicologist Ona Narbutienè.

This was not at all the case with operetta, which was considered not representative enough, not serious enough and, above all, not professional enough. It could not bring what a nascent society wanted, namely to quickly build a high-level musical culture.

The figures speak for themselves: between 1920 and 1940, Kaunas State Opera staged 62 shows: 58 operas and only four operettas. None of these were by Lithuanian authors:

- La Périchole, opera bouffe by Jacques Offenbach (first performed in Kaunas in 1931),

- Les Cloches de Corneville, comic opera by Robert Planquette (1932),

- Baron Tzigane, operetta by Johann Strauss (1934),

- Chanson d'Amour, Henri Bertés Singspiel based on the music of Franz Schubert (1938).

3 Located in Kaunas, the Lithuanian capital at that time.

4 Vladas Jakubėnas, Straipsniai ir recenzijos [Articles and reviews], vol. 1 (Vilnius: Lietuvos muzikos akademija, 1994), 287.

5 Ona Narbutienè, Muzikinis Kaunas 1920-1940 [Musical Kaunas in 1920-1940] (Kaunas: Šviesa, 1992), 17. 


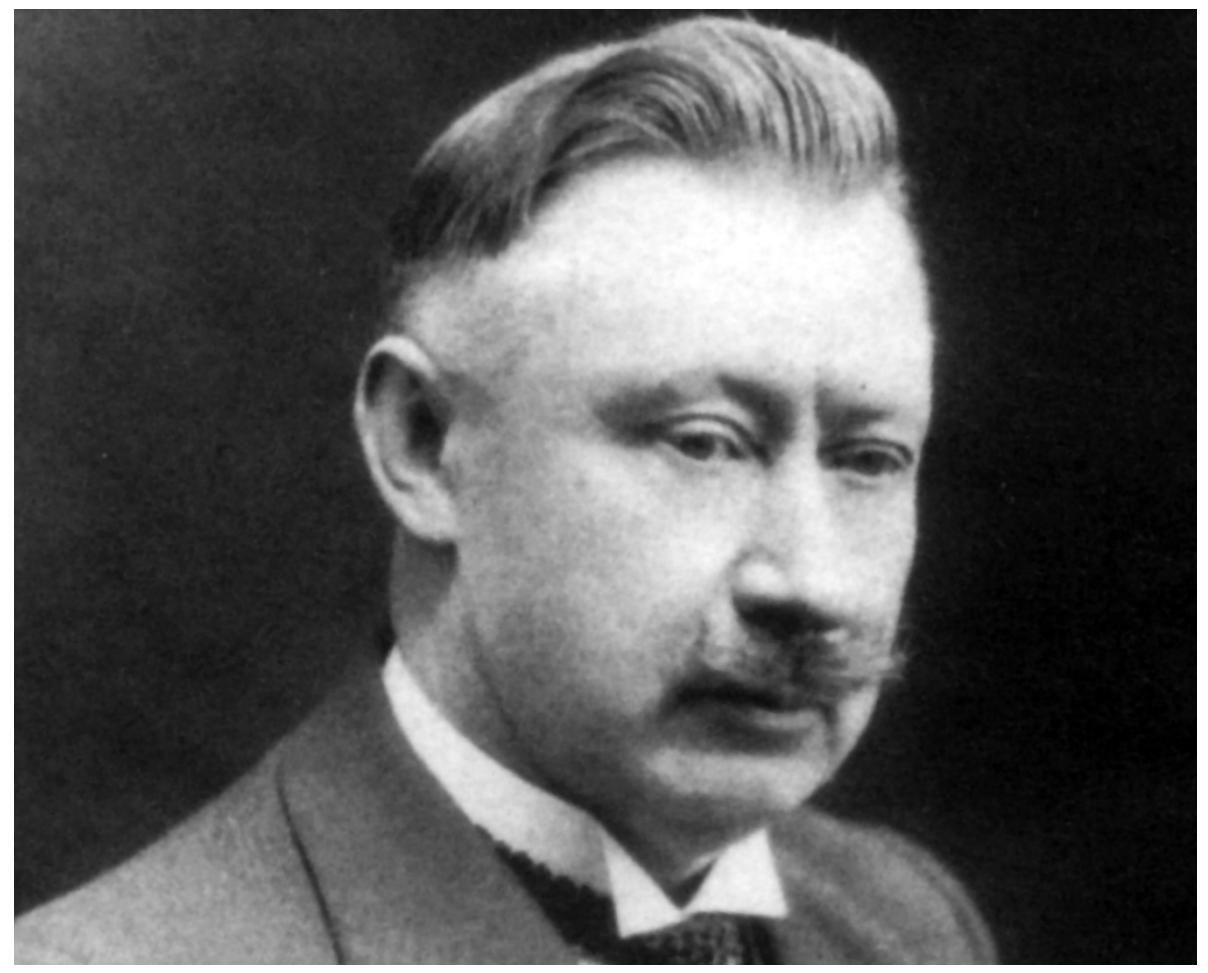

Picture r: Mikas Petrauskas (1885-1968)

Seen from this angle, one could easily say that the Lithuanian operetta simply did not exist during the inter-war period. But it did exist, only in a special way.

\section{The springboard for opera}

At the very beginning of the $2 \mathrm{O}^{\text {th }}$ century, just after the end of the ban on the press and education in the Lithuanian language in $1904,{ }^{6}$ the musical life of the main cities revolved around Societies of Songs and Theatre. They regularly organised Lithuanian Evenings, which included a play and a choir concert. "In the absence of a Lithuanian repertoire, the conductors began to compose it themselves." "The first operettas were created precisely for such evenings by Mikas Petrauskas, a choir conductor, singer, and composer.

6 The Lithuanian-language press was banned between 1864 and 1904, after the uprising for the liberation of Lithuania in 1863.

7 Jūratė Burokaitè, ed., Mikas Petrauskas, Straipsniai, laiškai, amžininku atsiminimai [Articles, letters, memories of contemporaries] (Vilnius: Vaga, 1976), 3. 
When in 1901 Petrauskas came to the St. Petersburg Conservatory to study singing, musical theory (with Anatoli Liadov), and composition (with Rimski-Korsakov), he immediately became involved in the activities of local Lithuanian Societies. For one of them, in 1903, he created his first operetta, The Chimney Sweep and the Miller ${ }^{8}$. It was a revival of an operetta written by the Polish composer Franciszek Ksawery Zaremba (1841-1923) to the libretto by F.N. Kamiński," for which "he had translated the text by a student," "'o changed the names of the characters, and added a folk dance at the end. Two years later (in 1905), for the presentation of this same operetta in Lithuania, Petrauskas added "his own music," namely, "a rather important overture" and "the ballet of the end." In the overture, he used

the motifs of popular songs and added the Lithuanian anthem (Lietuva, tèvyne mūsų), counterpointing with the Polish anthem (Jeszcze Polska nie zginęla) and a Polish song (Bože coš Polskę). ${ }^{12}$

According to the composer Juozas Tallat-Kelpša, Petrauskas "wanted to show that Lithuanians could cooperate with Poles in the field of culture."13 But the real reason was perhaps quite different, and much more pragmatic: for this performance he appealed not only to the Lithuanian singers who were few in number, but also to the Polish singers living in Vilnius, and thus tried to motivate them to participate in the city's musical scene.

In the same year of 1905, Petrauskas adapted for the Lithuanian public an operetta in three acts (four tableaux) by the French composer Gaston Serpette, Adam et Ève, based on a libretto by Ernest Blum and Raoul Toché (1886). After those two cases where he acted not really as a composer, but rather as an arranger, and after graduating from the St. Petersburg Conservatory in 1906, Petrauskas composed the first Lithuanian opera, a modest two-act musical drama on a historical subject, entitled Birute $\dot{e}^{\text {I4 }}$. For its staging in Vilnius in 1906, "musicians were sought in cafés and restaurants,

8 The operetta was created in 1905, in Vilnius. There are no photos left of this first Lithuanian operetta since Mikas Petrauskas was wanted by the tsar's police for active participation in the 1905 revolution (Burokaitè, Mikas Petrauskas, 172).

Original title: Kominiarz i młynarz czyli Zawalenie się wieży: komedya w jednym akcie ze śpiewami, 1885.

Burokaite, Mikas Petrauskas, 206.

Ibid., 206-7.

Ibid., 207.

Ibid., 208.

14 Based on the drama of the same name by Gabrielius Landsbergis-Žemkalnis. 
and one had to negotiate not only with them, but also with their bosses" or "to address musicians who worked in silent cinemas."

This first "almost opera", according to Juozas Tallat-Kelpša, ${ }^{16}$ although not really an operetta (because of the historical subject), was very important for the national consciousness. Despite the simplicity of its storyline and the music language, as well as lack of resources, this musical drama, created " just after regaining the right to press in the Lithuanian language, was something wonderful, something sacred", according to the participants. "They were all excited and proud to be a part of it." ${ }^{37}$ Petrauskas himself directed the show, but since he was wanted by the tsar's police for participation, along with other students, in the Russian revolution of 1905, his name on the poster was not mentioned, and no photos of this historic event were taken. ${ }^{18}$

An opera theatre is a heavy undertaking, both in human and financial terms. It is therefore quite logical that national opera would always begin its existence with modest forms that have a more symbolic than artistic value. This was the case in Lithuania for its very first 'opera' performance in 1636, with the musical drama of Italian playwright Virgilio Puccitelli (1599-1654), The Abduction of Helen (Elena's Il ratto), presented inside the Royal Palace of Vilnius. This was also the case with the 'first national opera' Birute by Mikas Petrauskas, presented in 1906 in the building of the current Vilnius Philharmonic.

When this historical drama was presented again in Lithuania in 1921, to celebrate its $15^{\text {th }}$ anniversary, it no longer matched the artistic level and quality of the musicians, which had both risen significantly:

Fifteen years ago, we were all proud, our tears flowed as we listened to him, but now Birute, although supplemented by other works of the composer, seemed extremely poor to everyone. ${ }^{19}$

The revival was thus disappointing, although, on the other hand, it demonstrated the progress towards professionalisation that had been

15 Narbutienè, Muzikinis Kaunas, 15, 18.

16 Burokaitè, Mikas Petrauskas, 209.

17 Ibid., 9.

18 Ibid., 253.

19 Algimantas Kalinauskas, “J. Karnavičiaus operos” [J. Karnavičius operas], in: Jūratė Burokaitè, Jurgis Karnavičius. Gyvenimo ir kūrybos kelias. Laiškai. Straipsniai apie kūrybą. Amžininku atsiminimai [Jurgis Karnavičius. The way of life and creation. Letters. Articles about creativity. Memories of contemporaries] (Vilnius: Petro ofsetas, 2004), 216. 
achieved over 15 years by the theatre troupe, and also the greater demands of the public.

In Klaipeda, the second Lithuanian city of the time, the operetta also played the role of 'a progressive introduction to opera'. In 1922, when this part of the country was still under French occupation, a local choir called Aida staged an operetta by Petrauskas entitled Consilium Facultatis. In 1927 it was staged again, and more professionally, by the teachers and students of the conservatory, with the help of the Klaipeda Singing Society. A year later, the same musical forces staged Birute by Petrauskas and then Faust by Charles Gounod. ${ }^{20}$ We clearly see the repetition of the same pattern in the construction of an opera culture: a progression from the operetta, through a musical drama, to the opera. In this progression, the operetta is not considered as a genre in its own right. In other words, it is not considered as a goal in itself. It serves just for testing, preparing, and mobilising musical and artistic forces for 'true opera', which is the ultimate goal of a culture that wants to be 'national'.

The main concern of Lithuanian society between the two world wars, at least when it came to music, was the desire to rapidly improve the quality of musicians. Last year I spoke at this conference about the choices made by the conservatories of the country, since they corresponded only to the real needs of musical institutions, such as symphony orchestras, and especially the State Opera. The operetta, which was a rather amateur undertaking and thus drew the level of professional musicians down, was both unappreciated and considered by the musicians themselves as harmful to their careers.

The composer Vladas Jakubenas, who was one of the main musical critics of the time, wrote upon his return from Riga in 1934:

The Latvian opera and the Latvian audiences follow really strange paths. A few years ago, Latvian opera turned to business. [...] The platitude and banality of music and content are not tolerable to any cultured spectator. [...] Operettas have had a negative influence on the performance of operas: the best artists, 'infatuated with operetta', have begun to show signs of artistic decline; the same thing happened with the orchestra [...].".

20 Daiva Kšaniené, "Lietuviškam Klaipedos operos teatrui - 75-eri” [Lithuanian Klaipeda Opera House - 75 years], Durys, https://durys.diena.lt/lietuviskam-klaipedos-operos-teatrui-75-eri/7878.

21 Jakubènas, Straipsniai ir recenzijos, 127. 
In 1932, when Robert Planquette's operetta Les Cloches de Corneville was premiered at the Kaunas Opera Theatre, a heated discussion followed among Lithuanian composers on the issue "should we stage operettas in the opera theatre?"'2 Despite strong opposition from the leading composers of the time, such as Vytautas Bacevičius, another operetta, The Gypsy Baron by Johann Strauss, was finally staged two years later, in 1934. Paradoxically, it was a total failure: "the lightness of the true Viennese style was not grasped", "the operetta gave the impression of being an opera." ${ }^{\text {"23 }}$ This proves that not only was the operetta very poorly integrated into cultural life, but also that it was totally foreign to the Lithuanian culture of the time.

Moreover, even after the Second World War, the word 'operetta' among the community of Lithuanian composers was used to designate incompetence or a lack of value. For example, in 1948, when the composer Konstantinas Galkauskas was leafing through a collection of Soviet songs, which the secretary of the Union of Composers presented to him as examples to follow, he replied, "I don't think it's serious music, it's like an operetta."

\section{Operetta at the service of the national awakening}

All Lithuanian operettas from the interwar period were written by a single composer, Mikas Petrauskas. In addition, they were all written abroad, in St. Petersburg (2), Switzerland (1) and the United States (14):

In St Petersburg:

Kaminkretys ir malūnininkas [The Chimney Sweep and the Miller] (1903)

Adomas ir Ieva [Adam and Eve] (1905)

In Zurich (Switzerland):

Šienapjūtè [Hay-making] (1910)

22 Jonas Bruveris, "Muzikos atlikimo menas. Muzikinis teatras. Opera" [The Art of Performing Music. Musical theater. Opera], in Lietuvos muzikos istorija - II, Nepriklausomybés metai 1918-1940 [Lithuanian music history - II, Independence years 1918-1940], ed. Algirdas J. Ambrazas (Vilnius: LMTA, 2009), 127 (117-57).

23 Jakubėnas, Straipsniai ir recenzijos, 457, 166.

24 "Report of A. Klenickis, Executive Secretary of the Organizing Committee of the Union of Soviet Composers of the Lithuanian SSR, at the First Congress of Soviet Composers of the Lithuanian SSR, Vilnius, January 23, 1948," in Muzika 1940-196o. Dokumentu rinkinys [Music from 1940 to 1960. A set of documents] (Vilnius, [s. n.], 1992), 86. 


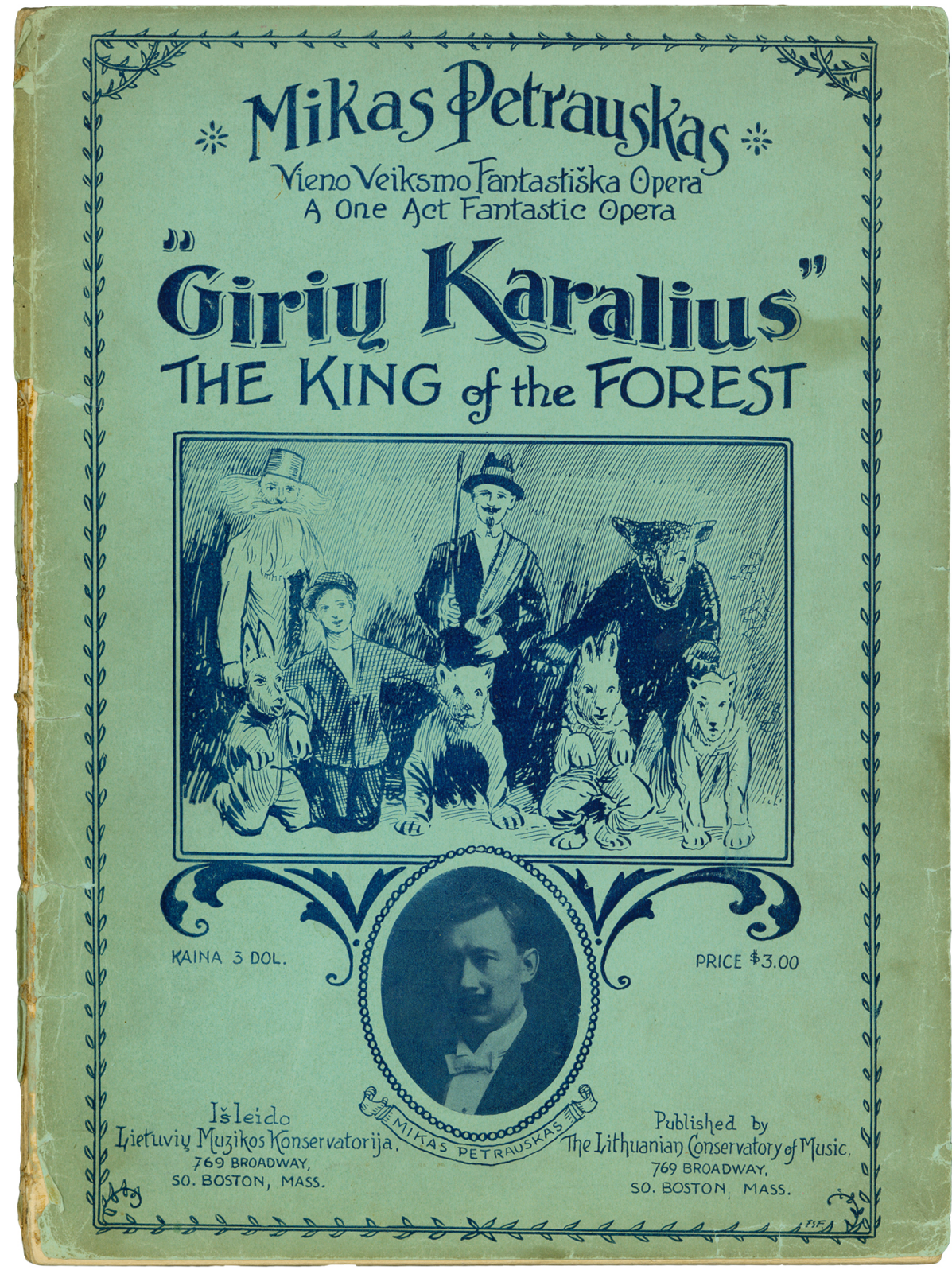

Picture 2: The cover of the score of "King of the Forest" by Mikas Petrauskas (1916) 
In the United States:

Užburtas kunigaikštis [The Enchanted Duke] (1913)

Šventoji naktis [Holy Night] 1913 (1916?)

Consilium facultatis (1915)

Vestuvés [Wedding] (1915)

Tarnaite pamoke [The Maid Taught a Lesson] (1915)

Velnias išradejas [Devil Inventor] (1915, two acts light opera)

Apvesdinkit ir mane [Find me a Wife, too] (1916)

Giriu karalius [King of the Forest] (1916, one-act fantastic opera)

Lietuviškas milijonierius [Lithuanian Millionaire] (1916)

Elgetos dukté - karaliené [Beggar's Daughter a Queen] (1917)

Pirmoji gegužès [The First of May] (1920)

Vaikas ar mergaitè? [A Child or a Girl?] (1922)

Vargonininko vestuves [The Organist's Wedding] (1923)

Prieglauda [An Asylum] (1924)

This is a curiosity and also a symptomatic fact. This means, on the one hand, that the operetta did not find its raison d'être in the Lithuanian culture of this period. On the other hand, it means that Petrauskas must have had very personal reasons for continuing this activity on his own and almost throughout his career.

One of his reasons was the fact that he lived abroad for a large part of his life. He lived in the United States between 1907 (after his forced departure from Lithuania for political reasons) and 1930, with some interruptions to make trips to France, where he studied composition with Charles-Marie Widor, ${ }^{25}$ to Italy, where he improved his vocal technique with Angelo Masini (in 1911), ${ }^{26}$ and to Lithuania, where he staged some of his operettas in provincial theatres. Living mainly abroad, Petrauskas had an acute awareness of the importance of national culture.

When he arrived in the United States, a large community of Lithuanians, scattered in different large cities, had only parish choirs and folk-dance groups for 'cultural institutions'. Composing and staging operettas in these culturally disadvantaged environments was part of the composer's personal commitment to a collective cause, which he fought hard for. His activi-

25 Burokaitè, Mikas Petrauskas, 199.

26 Danute Petrauskaitè, Lietuvių muzikinè kultūra Jungtinèse Amerikos Valstijose 187o1990 [Lithuanian musical culture in the United States from 1870 to 1990] (Vilnius: Dailès akademijos leidykla, 2015), 283. 
ty was constructed as an educational, pedagogical, and ideological ensemble (he still adhered to the ideas of socialism that he had picked up in 1905). When he arrived in a town where a large Lithuanian community lived, he first assembled members of the community and organised a large choir, then he set up a school of music which he called a 'conservatory', to allow choristers to perfect their musical theory and learn to play an instrument, and subsequently he would produce musical performances, focusing exclusively on his own operettas. This pattern was transported from one American city to another, adapting to the situation, the needs of local immigrants and the possibilities of the place.

This push for a 'collective' culture also defined the level of operettas. Their extreme simplicity can be explained by the fact that they had educational and non-commercial purposes, and often the shows were unprofitable. The vocal parts of Petrauskas's operettas are written in such a way that they can easily be interpreted by amateurs who cannot read music and do not have suitable voices. That is probably why it was sometimes difficult for the composer to find the right balance between the simplicity and poverty of the musical language - or, as Adorno said using Willy Haas' expression, to write "bad music of good quality."

In worker communities the operetta was intended, first, to interest and attract workers to their own culture, to bring them closer to their language, to their roots, by offering them an art comprehensible, simple, reusable, and multiplied at will and by minimal means.

My wish, when I arrived in the United States - said the composer - was and is always to attract as many people as possible into music, so that when I leave here, they can conduct choirs and small orchestras by themselves ... ${ }^{28}$

In this sense, his work was very important. In a local Lithuanian newspaper, we read:

The faces of the listeners reflected these extraordinary feelings, hearing everything that was waking up in front of them [...]. These simple but dear melodies captured the Lithuanian spirit and carried it into the sky of a distant homeland, where similar voices are heard. ${ }^{29}$ 


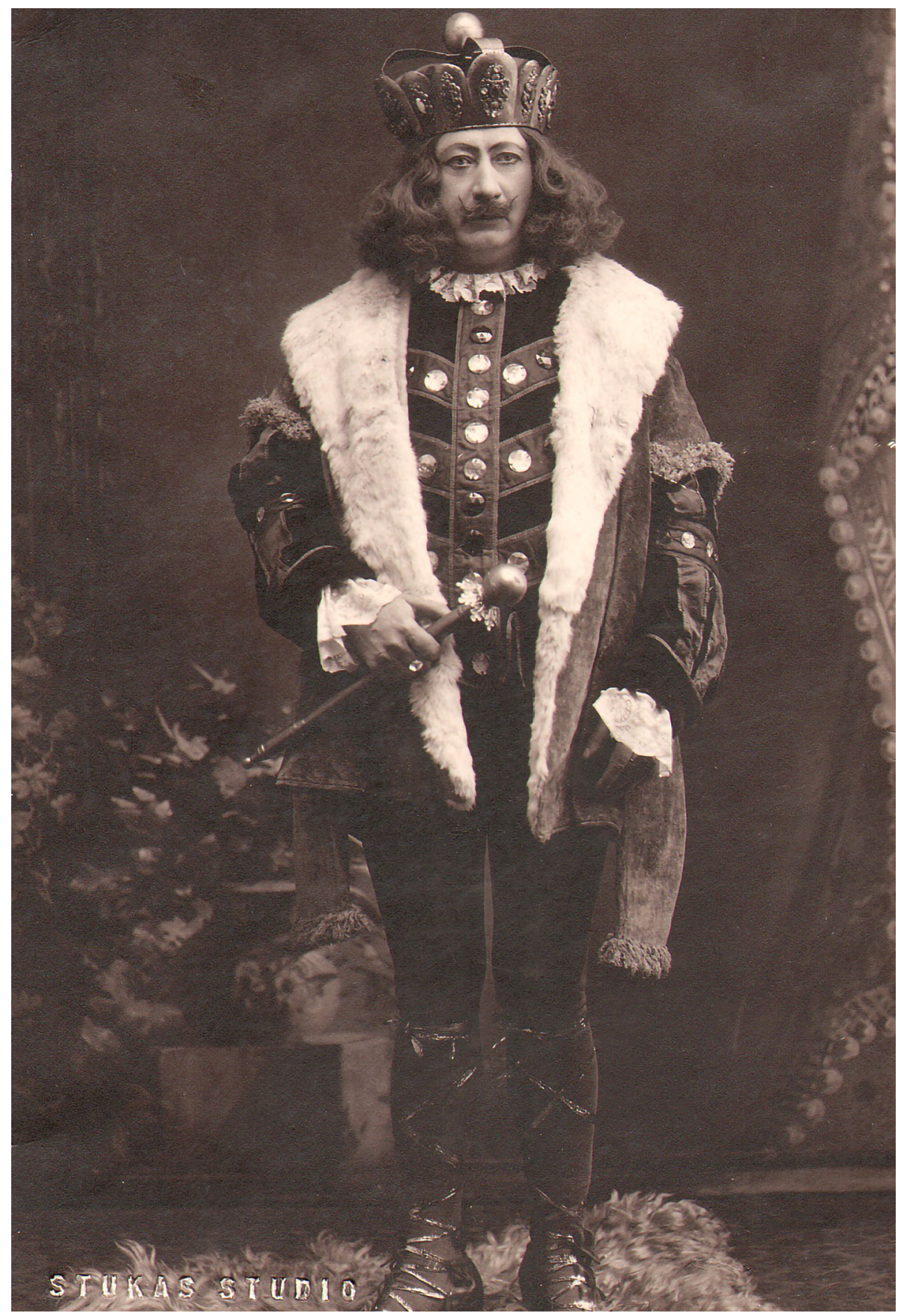

Picture 3: Petrauskas in the role of the snake in his opera Egle the Queen of Snakes (1924, Boston) 
This activity soon bore fruit: operettas contributed not only to the mobilisation and education of singers, but also to the promotion of community coexistence based on culture, and not only on nationality. Meanwhile, in Lithuania, the operetta did not have to play that role and therefore was intended for amateurs instead, and considered just as a threshold 'not professional enough' that had to be quickly crossed on the journey to something better.

In Lithuania, Petrauskas tried to transpose his vision of operetta as popular art, accessible to all. As early as 1919 he was possessed by the idea that "it was necessary to educate people," and proposed to "set up 2-3 troupes of operetta singers to bring music to every corner of Lithuania." ${ }^{30}$ In 1925, he deepened this desire in a press article explaining why the creation of a 'popular opera' or an 'opera of the people', which he defined as 'operetta', was important:

a. The Popular Opera will be a cultural factor among young people.

b. The Popular Opera will promote and support Lithuanian art.

c. The aim of the Popular Opera is to offer artistic food to the public, and above all to arouse the interest of young people, because here young people, young artists, have the opportunity to act, develop, and perfect themselves in the field of art.

$d$. The centre of the Popular Opera is in Kaunas [...] but the whole direction is defined so that, during the summer, it will be possible to visit all Lithuanian cities and villages [...]. Young people, take an interest! This is your first and best opportunity to study the art of music and move forward. ${ }^{31}$

Unfortunately, this idea did not resonate in Lithuania. Critics and the public responded unfavourably to the work of Petrauskas, and did not understand the meaning and usefulness of the creation of the Popular Opera.

Kaunas's audience, having already seen many high-level performances of the State Theatre [...], had the same requirements for the Popular Opera as for the professional opera, despite the fact that these were the first steps of the amateurs on stage. ${ }^{32}$ 
After the disappointing reception of the first shows, the Popular Opera ceased to exist. ${ }^{33}$

Now one could say that the ideas and methods of Petrauskas corresponded to those of the then current musical comedies. His goal was to create a school for young people so that they could learn the performing arts and flourish in this field, except that his idea had no economic plan, no solid financial basis when compared to musicals, and was instead more educational in intent.

\section{Conclusion: Between the opera and the cabaret}

The operetta in Lithuania between the two world wars was considered neither a serious art nor an entertainment. It was considered as something in-between opera and the cabaret concerts given in the luxurious restaurants of the capital (like Metropolis or Versalis) or upmarket cafés (like Konrad).

The operetta failed to expand the space it needed to function, and this may be the main reason why it never became a fully fledged genre in Lithuania. On the one hand, the opera occupied the entire space of musical high culture, while on the other, the cabaret monopolised that of entertainment.

The genre of operetta was thus denied a very important source of revenue, while the cabaret offered audiences entertainment with variety songs that presented in a theatrical way comic or lyrical situations drawn from daily life. The parodies, monologues, funny stories or love stories were sung and staged very professionally by the stars of variety shows, such as Danielius Dolskis or Antanas Šabaniauskas. The operetta was therefore neither professional nor profitable enough compared to the opera and cabaret.

In today's Lithuanian culture, however, the operetta has found its rightful place since it is no longer considered as a danger to either the national culture or the professional reputations of singers or musicians. It occupies a specific and stable niche in the cultural economy, although it has still not attracted the interest of Lithuanian composers.

\section{To sum up}

- The inter-war period was far too short (around 20 years) for the development of opera and operetta at the same time.

33 Ibid., 72. 
- The operetta did not offer professional singers the prestige they expected, based on their professional level.

- Standing between the two opposing genres, opera and cabaret, the operetta did not have the means (financial or artistic) to get established and therefore to develop.

- The operetta played a role in the introduction to opera as well as a role in national awakening through bringing the Lithuanian diaspora abroad to the roots of their own culture and promoting music education within the community.

\section{Bibliography}

Adorno, Theodor W. Théorie esthétique. Paris: Klincksieck, 1989.

Ambrazas, Algirdas J., ed. Lietuvos muzikos istorija - II, Nepriklausomybès metai 1918-1940 [Lithuanian music history - II Independence years 19181940]. Vilnius: LMTA, 2009.

Brindejont-Offenbach, Jacques. Cinquante ans d'opérette [Fifty years of operetta]. https://www.artlyriquefr.fr/dicos/Cinquante\%20ans\%20-\%2ooperette.html.

Bruveris, Jonas. "Muzikos atlikimo menas. Muzikinis teatras. Opera” [The Art of Performing Music. Musical theater. Opera]. In Lietuvos muzikos istorija - II, Nepriklausomybes metai 1918-1940 [Lithuanian music history - II, Independence years 1918-1940], edited by Algirdas J. Ambrazas, 117-57. Vilnius: LMTA, 2009.

Burokaitè, Jūratè, ed. Mikas Petrauskas, Straipsniai, laiškai, amžininku atsiminimai [Articles, letters, memories of contemporaries]. Vilnius: Vaga, 1976.

Burokaitè, Jūratė, ed. Jurgis Karnavičius. Gyvenimo ir kūrybos kelias. Laiškai. Straipsniai apie kürybą. Amžininkų atsiminimai [Jurgis Karnavičius. The way of life and creation. Letters. Articles about creativity. Memories of contemporaries]. Vilnius: Petro ofsetas, 2004.

Jakubėnas, Vladas. Straipsniai ir recenzijos [Articles and reviews]. Vol. 1. Vilnius: Lietuvos muzikos akademija, 1994.

Kalinauskas, Algimantas. "J. Karnavičiaus operos" [J. Karnavičius operas]. In: Jūratė Burokaitè, Jurgis Karnavičius. Gyvenimo ir kūrybos kelias. Laiškai. Straipsniai apie kūrybą. Amžininku atsiminimai [Jurgis Karnavičius. The way of life and creation. Letters. Articles about creativity. Memories of contemporaries]. Vilnius: Petro ofsetas, 2004. 
Kšanienè, Daiva. "Lietuviškam Klaipedos operos teatrui - 75-eri" [Lithuanian Klaipeda Opera House - 75 years]. Durys. https://durys.diena.lt/ lietuviskam-klaipedos-operos-teatrui-75-eri/7878.

Muzika 1940-1960. Dokumentu rinkinys [Music from 1940 to 1960. A set of documents]. Vilnius, [s. n.], 1992.

Narbutiene, Ona. Muzikinis Kaunas 1920-1940 [Musical Kaunas in 1920-1940]. Kaunas: Šviesa, 1992.

Petrauskaitè, Danutè. Lietuviu muzikinè kultūra Jungtinèse Amerikos Valstijose 1870-1990 [Lithuanian musical culture in the United States from 1870 to 1990]. Vilnius: Dailès akademijos leidykla, 2015. 